преподаватель кафедры административного менеджмента и альтернативных источников энергии, Винницкий национальный аграрный университет (21008, г. Винница, ул. Солнечная, 3, e-mail: shevchukhv@gmail.com).

УДК 349.41

DOI: $10.37128 / 2411-4413-2021-3-3$

\section{ДЕРЖАВНИЙ ЗЕМЕЛЬНИЙ БАНК: ICTOРІЯ СТВОРЕННЯ ТА РОЗВИТКУ В УКРАЇ̈I TA CBITI}

ЛОГОША Р.В., доктор економічних наук, доцент кафедри аграрного менеджменту та маркетингу ХАЕЦБКА О.П,
кандидат економічних наук, доцент,
завідувачка кафедри економіки
та підприємнццкої діяльності,
Віннццький національний аграрний університет
(м. Вінниця)

У статті проведений ретроспективний аналіз створення $і$ розвитку Державного земельного банку в Україні. Обтрунтовано, що для ефективного функиіонування ринку землі, крім інших складників, необхідне функиіонування належної інфраструктури та системи державного контролю, коли Державний земельний банк або інша спеціалізована державна установа займає важливе місце $i$ виконує функиії регулятора ринку та розпорядника земельних ділянок держави.

Проведено дослідження особливостей функціонування систем іпотечного кредитування у краӥнах світу і можливість застосування зарубіжного досвіду для розвитку іпотечних відносин у сільському господарстві України.

Досконала інфраструктура іпотечного та кредитного ринку забезпечує високу ефективність функиіонування іпотечних відносин. Визначено, щзо елементами інфраструктури іпотечно-кредитного ринку в багатьох крайнах є: земельний кадастр та централізоване кредитне бюро з доступом банків до їхньої інформачії у режимі реального часу, иентралізована база даних нерухомості; фондові біржі, клірингові иентри та клірингова система центрального банку; спеціалізовані банки та структури (корпорації, фонди, управління); державні иілььові гарантійні фонди.

Нині, коли українські сільськогосподарські виробники використовують землю на правах оренди, зростає дочільність створення відповідних державних установ, зокрема й заснування Державного земельного (іпотечного) банку. Його функиіонування сприятиме: розвитку іпотеки сільськогосподарських земель; поліпшить умови середньо- та довгострокового кредитування під заставу земельних ділянок для забезпечення потреб аграрних товаровиробників та населення, яке проживає у сільській місиевості; розширить можливості сільськогосподарського виробництва; забезпечить регулювання процесу ціноутворення на земельні ділянки; забезпечить ефективну діяльність механізму перерозподілу земель; сприятиме залученню інвестицій у сільське господарство та додаткові вкладення у землі сільськогосподарського призначення для збереження ӥх родючості тощзо.

Ключові слова: Державний земельний банк, ринок землі, система іпотечного кредитування, інфраструктура ринку землі, обіг земель, земельна реформа.

Табл.: 1. Літ.: 22. 


\title{
STATE LAND BANK: HISTORY OF CREATION AND DEVELOPMENT IN UKRAINE AND THE WORLD
}

\author{
LOHOSHA Roman, \\ Doctor of Economic Sciences, Associate Professor \\ of the Department of Agricultural Management and Marketing
}

KHAIETSKA Olha, Candidate of Economic Sciences, Associate Professor, Head of the Department of Economics and Entrepreneurship, Vinnytsia National Agrarian University

(Vinnytsia)

The article presents retrospective analysis of the creation and development of the State Land Bank in Ukraine. It is substantiated that for the effective functioning of the land market, among other components, the functioning of proper infrastructure and system of state control is necessary, when the State Land Bank or other specialized state institution plays an important role and performs the functions of the market regulator and land manager.

Study of the peculiarities of the functioning of mortgage lending systems at foreign countries and the possibility of applying foreign experience for the development of mortgage relations in agriculture of Ukraine are conducted.

The perfect infrastructure of the mortgage and credit market ensures high efficiency of mortgage relations. It is identified that important elements of the infrastructure of the mortgage market in many countries are: land cadastre and centralized credit bureau with access of banks to their information in real time, centralized real estate database; stock exchanges, clearing centers and the clearing system of the central bank, specialized banks and structures (corporations, funds, management), state trust guarantee funds.

In today's conditions, when Ukrainian agricultural producers use land on lease, the expediency of creating the appropriate state institutions, including the establishment of the State Land (Mortgage) Bank, is growing. Its functioning will promote to: the development of mortgages on agricultural land; improve the conditions of medium-and long-term lending secured by land to meet the needs of agricultural producers and the population living in rural areas; expand the possibilities of agricultural production; provide regulation of the pricing process for land plots; ensure the effective operation of the land redistribution mechanism; will help attract investment in agriculture and additional investments in land to maintain its fertility, etc.

Key words: State Land Bank, land market, mortgage lending system, land market infrastructure, land turnover, land reform.

Tabl.: 1. Ref.: 22.

\section{ГОСУДАРСТВЕННЫЙ ЗЕМЕЛЬНЫЙ БАНК: ИСТОРИЯ РАЗВИТИЯ В УКРАИНЕ И МИРЕ}

ЛОГОША Р.В.,

доктор экономических наук, доцент кафедры аграрного менеджмента и маркетинга 


\section{ЕФМ}

http://efm.vsau.org/

ХАЕЦКАЯ О.П.,

кандидат экономических наук, доцент, заведующая кафедрой экономики

и предпринимательской деятельности,

Винницкий национальный аграрный университет

(2. Винница)

В статье проведен ретроспективный анализ создания и развития Государственного земельного (ипотечного) банка в Украине. Обоснованно, что для эффективного функиионирования рынка земли, кроме других составляющих, необходимо функиионирование надлежащей инфраструктуры и системы государственного контроля, когда Государственный земельный (ипотечный) банк или иное специализированное государственное учреждение занимает важное место и выполняет функции регулятора рынка и распорядителя земельных участков государства.

Проведено исследование особенностей функиионирования систем ипотечного кредитования в странах мира и возможность применения зарубежного опыта для развития ипотечных отношений в сельском хозяйстве Украинь.

Совершенная инфраструктура ипотечного и кредитного рынка обеспечивает высокую эффективность функиионирования ипотечных отношений. Определено, что элементами инфраструктуры ипотечно-кредитного рынка во многих странах являются: земельный кадастр и иентрализованное кредитное бюро $c$ доступом банков $\kappa$ их информации в режиме реального времени, иентрализованная база данных недвижимости; фондовые биржи, клиринговые центры и клиринговая система иентрального банка; специализированные банки и структуры (компании, фонды, управление); государственные иелевые гарантийные фонды.

В условиях, когда украинские сельскохозяйственные производители используют землю на правах аренды, растет целесообразность создания соответствующих государственных учреждений, в том числе и основания Государственного земельного (ипотечного) банка. Его функиионирование будет способствовать: развитию ипотеки сельскохозяйственных земель; улучшит условия средне- и долгосрочного кредитования под залог земельных участков для обеспечения потребностей аграрных товаропроизводителей и населения, проживающего в сельской местности; расширит возможности сельскохозяйственного производства; обеспечит регулирование процесса ценообразования на земельные участки; обеспечит эффективную деятельность механизма перераспределения земель; будет способствовать привлечению инвестиций в сельское хозяйство и дополнительные вложения в землю для сохранения её плодородия и тому подобное.

Ключевые слова: Государственный земельный банк, рынок земли, система ипотечного кредитования, инфраструктура рынка земли, оборот земель, земельная реформа.

Табл.: 1. Лит.: 22.

Постановка проблеми. Досвід розвинутих країн свідчить, що визначальною умовою успішного розвитку аграрного сектору є наявність дієвої системи земельно-іпотечного кредитування, ключовою ланкою якої виступають спеціалізовані кредитні інститути. Успішне функціонування іпотечних земельних банків у різних країнах сприяє підвищенню ефективності діяльності аграрних виробників, враховуючи їх потреби та особливості ведення бізнесу.

В Україні, у зв’язку із прийняттям Закону України «Про внесення змін до 


\section{EФM}

http://efm.vsau.org/

деяких законодавчих актів України щодо умов обігу земель сільськогосподарського призначення» [1], який передбачає відкриття ринку земель сільськогосподарського призначення та створення його відповідної інфраструктури, постало питання щодо створення спеціального кредитнофінансового інституту, діяльність якого сприяла б надходженню інвестицій у сільське господарство. Для реалізації зазначених цілей та забезпечення ефективного функціонування ринку сільськогосподарських земель необхідним є створення спеціалізованої фінансової установи, якою має стати Державний земельний банк, що буде наділений функціями, які забезпечать ефективне управління земельними ресурсами державної власності, фінансово-кредитну діяльність, підтримку малого сільськогосподарського бізнесу. Тобто, Державний земельний банк України буде поєднувати в своїй діяльності елементи іпотечного, аграрного та земельного банків.

Аналіз останніх досліджень і публікацій. Проблемам функціонування системи земельно-іпотечного кредитування та ролі спеціальних кредитних установ у розвитку сільського господарства присвячені праці багатьох вчених, а саме: Данкевича В.С. [7], Дем'яненка М.Я., Калетніка Г.М. [21, 22], Кириленка І.Г. [9], Гончарук I.В. [21, 22], Смчик Т.В. [21, 22], Лупенка Ю.О. [5, 15], Третяка А.М., Саблука П.Т. [4], Ходаківської О.В. [5] та ін. Однак недостатньо висвітленими залишаються питання щодо особливостей діяльності Державного земельного банку в Україні, механізму іпотечного кредитування в сільському господарстві та ряду інших важливих питань.

Формулювання цілей статті. Метою дослідження $є$ аналіз системи земельно-іпотечного кредитування та діяльності спеціальних кредитних установ у сільському господарстві України та світу.

Виклад основного матеріалу дослідження. Історичний екскурс розвитку земельних відносин на території України визначає, що земельне питання було одним із нагальних, яке мала визначити революція в Російській імперії. Політика Центральної Ради в аграрному питанні не призвела до його розв’язання. Так, 29 квітня 1918 р. у Києві відбувся з’іззд хліборобів України, який проголосив великого землевласника - генерала П. Скоропадського Гетьманом усієї України, який визначив, що основою його господарської політики буде збереження і забезпечення права приватної власності як основи державного розвитку та цивілізації. В аграрній політиці гетьман та його уряд мали за мету створення великого шару середніх хліборобів-власників, які б отримали свою частку землі через парцеляцію і від розпродажу великих маєтків. У вихідні засади реформи П. Скоропадським ставилися такі принципи: передача землі селянам за платню; виплата селянських грошей за землю, яка купується; передача землі не безземельним селянам, а малоземельним [2, c. 285].

Під час Гетьманату 1918 р. фінансову допомогу селянам та державі у втіленні в життя реформи мав провадити Державний Земельний банк. Однак він 


\section{EФM}

http://efm.vsau.org/

не встиг виконати свою історичну роль у наділенні землею малоземельних селян та у створенні глибокого й міцного шару хліборобів-середняків в Україні. У середині грудня 1918 року Гетьманат було повалено. Разом із його ліквідацією до занепаду прийшла й аграрна реформа щодо створення селянинавласника та iï акумулятор і фінансовий рушій - Державний Земельний банк [3, c. 27].

Сьогодні розвиток земельних відносин $є$ невід'ємною та важливою складовою загальної аграрної реформи в Україні, яка повинна проводитись на основі визначених законодавством принципів і механізмів комплексного регулювання земельних відносин в умовах ринку з урахуванням: гарантування прав громадянам України - власникам земельних ділянок сільськогосподарського призначення щодо володіння, користування та вільного вибору розпорядження земельною власністю; забезпечення охорони земель, підвищення ефективності державного контролю за використанням земель сільськогосподарського призначення, збереження й підвищення родючості грунтів; введення в обіг земельного капіталу, створення умов для його капіталізації; формування відповідної інфраструктури регулювання обігу земель сільськогосподарського призначення; забезпечення захисту соціальноекономічних інтересів власників земельних ділянок і сільських громад; дотримання публічності діяльності органів виконавчої влади та місцевого самоврядування у питаннях розпорядження й використання земель; недопущення надмірної концентрації земель сільськогосподарського призначення у власності та користуванні; розширення повноважень органів місцевого самоврядування у питаннях регулювання користуванням та розпорядженням землями сільськогосподарського призначення на визначених законодавством сільських територіях [4, с. 131].

За визначенням Лупенка Ю.О. та Ходаківської О.В., із урахуванням політичної та економічної ситуації в Україні, обіг земель сільськогосподарського призначення потребує прозорого й одночасно жорсткого регулювання державою за контролю структур громадянського суспільства, здійснюваного 3 урахуванням потреб українських товаровиробників та національних інтересів [5, с. 12].

Залучення земель сільськогосподарського призначення до ринкового обігу має враховувати соціальні, економічні й екологічні чинники. Передусім соціальний фактор має відношення до врахування інтересів селян; економічний - до купівлі-продажу, застави, оренди та обміну сільськогосподарських земель, здійснення ефективної господарської діяльності; екологічний - до раціонального й екологобезпечного використання земель [6, с. 69].

В умовах запуску ринку земель сільськогосподарського призначення в Україні нагальною потребою $є$ проведення якісної інвентаризації земель сільськогосподарського призначення, оновлення Державного земельного 
кадастру, а також супутникове картографування території України, оскільки сьогодні немає чітких даних щодо кількісних параметрів землеволодіння у країні. Без якісної інвентаризації земель сільськогосподарського призначення дозвіл на продаж сільськогосподарських земель в Україні призведе до виникнення корупційних схем. Для ефективного функціонування ринку земель сільськогосподарського призначення, крім інших складників, необхідне функціонування належної інфраструктури та системи державного контролю, коли Державний земельний банк або інша спеціалізована державна установа, займає важливе місце і виконує функції регулятора ринку та розпорядника земельних ділянок держави.

Досліджуючи інформаційне забезпечення ринкових операцій, слід зауважити, що вагомою проблемою для вітчизняних товаровиробників сільськогосподарської продукції $є$ постійний дефіцит капіталу. Запорукою успішного розвитку аграрного сектора економіки $є$ наявність дієвої системи земельно-іпотечного кредитування, ключовою ланкою якої виступають кредитні інститути - спеціалізовані іпотечні банки та страхові компанії.

Нині, однією із вагомих причин повільної трансформації земельних відносин до ринкового типу є недосконалість інфраструктурного забезпечення операцій із землями сільськогосподарського призначення.

На думку Данкевича В.С., визначальними елементами інфраструктури ринку земельних ресурсів $\epsilon$ діяльність торгових домів та спеціалізованих підприємств, які здійснюють трансакції із земельними ділянками. Процес проведення земельних торгів на базі спеціалізованих організацій, що відповідають поставленим до них вимогам і пройшли відповідні тендери, гарантує високу ефективність цих торгів та прозорий механізм ринкових операцій із сільськогосподарськими землями [7, с. 332].

В Україні, 3 впровадженням ринку земель сільськогосподарського призначення, стане необхідним ведення виваженої політики щодо консолідації земель та переважної їх концентрації у державній власності. Ключова роль у виконанні цього завдання належатиме Державному земельному банку, як основному фонду земель державної власності.

Слід зазначити, що ідея створення такого спеціалізованого банку була передбачена 3 введенням із 1 січня 2002 р. Земельного кодексу України, зокрема, в його Прикінцевих положеннях (розділ IX ч. 4) [8]. Проте, це положення так і не було виконано протягом останніх майже двадцяти років, хоча на розгляд Верховної Ради України неодноразово подавалися відповідні законопроєкти.

Ще у 2008 році Голова Верховної Ради України зазначав, що Україна має повернутися до ідеї заснування Державного земельного банку - державного агенту з купівлі та продажу земель будь-якого призначення, що забезпечить простий та прямий доступ землевласника до фінансових ресурсів. У статутний фонд такого банку, крім грошових коштів, повинні бути передані ще й державні 


\section{EФM}

http://efm.vsau.org/

земельні сільськогосподарські активи, а юридично врегульована процедура застави землі дозволила б знизити вартість обігових коштів для реальних сільгоспвиробників [9, с. 14].

Україна, запозичуючи досвід розвинутих країн і розуміючи важливість розвитку аграрного сектора, у 2012 році розпочала процес створення спеціалізованої фінансової установи - Державного земельного банку. Рішення про створення цієї фінансової установи було передбачено Постановою Кабінету Міністрів України від 2 липня 2012 року № 609, яка передбачає створення публічного акціонерного товариства «Державний земельний банк» зі статутним капіталом 120 млн грн [10]. Статутний капітал банку формується за рахунок коштів Державного бюджету України, грошових внесків акціонерів та внесення до статутного капіталу земельних ділянок, зокрема сільськогосподарського призначення. Згідно з проєктом Закону України від 10.04.2009 р. № 4337 частка держави у статутному капіталі Державного земельного банку не може становити менше 60\%, проте, у процесі створення, весь статутний капітал належав державі. Передбачалося, що Державний земельний банк створювався у формі відкритого акціонерного товариства через випуск простих іменних акцій у бездокументарній формі. Вартість земельних ділянок, які передаються для формування статутного капіталу Державного земельного банку, визначається на підставі експертної грошової оцінки, проведеної у порядку, встановленому законодавством на час внесення майна до статутного капіталу. Перелік та розміри земельних ділянок державної власності, які вносяться до статутного капіталу Банку, визначаються відповідними органами виконавчої влади i затверджуються Кабінетом Міністрів України в розрізі областей, міст Києва i Севастополя [11].

До вищевказаного законопроєкту були внесені поправки, які передбачали створення такого спеціалізованого банку з метою:

1) забезпечення сприятливих умов для розвитку економіки та сільського господарства, запуску й успішного функціонування ринку земель, підтримки сільськогосподарських товаровиробників, зміцнення та реалізації виробничого і торгового потенціалу сільського господарства, а також одержання економічного прибутку від здійснення банківських операцій та провадження іншої діяльності відповідно до законодавства;

2) можливості формування статутного капіталу банку за рахунок не тільки грошових внесків, а також за рахунок внесків у вигляді земельних ділянок;

3) надання права банку здійснювати операції із земельними ділянками та майновими правами на земельні ділянки відповідно до законодавства України у сфері земельних відносин та свого статуту.

Розроблена модель Державного земельного банку, як окремого самоокупного фінансового інституту, передбачала, що він забезпечуватиме управління землями сільськогосподарського призначення державної власності, 


\section{EФМ \\ http://efm.vsau.org/}

включаючи консолідацію, купівлю-продаж, міну і здачу землі в оренду, та виконуватиме функцію із реалізації державних кредитних програм, кредитуватиме аграріїв під 8-12\% річних, передусім для середнього і малого бізнесу в сільській місцевості. Банку було надане право формувати статутний капітал за рахунок внесків у вигляді земельних ділянок. Запрацювати Державний земельний банк повинен був тільки після введення ринку земель сільськогосподарського призначення. На той час в Україні діяв мораторій на купівлю-продаж земель сільськогосподарського призначення, для зняття якого необхідно було прийняти закон про ринок землі [12, с. 111-112].

В умовах глобалізації світової економіки основними завданнями Державного земельного банку є: консолідація земельних ділянок і передача їх в оренду; збільшення відсотка оренди державних земель; фінансова підтримка розвитку малого i середнього агробізнесу; підтримка державних програм розвитку аграрного сектора економіки на основі поворотного фінансування.

Державний земельний банк здійснює кредитування [11]:

- сільськогосподарських підприємств, установ та організацій (включно 3 фермерськими, рибальськими та рибницькими господарствами), основним видом діяльності яких є вирощування, переробка та збут самостійно виробленої сільськогосподарської продукції, виручка від реалізації якої становить не менше 50\% загальної суми виручки;

- підприємств, установ та організацій, основним видом діяльності яких $є$ виробництво та зберігання сільськогосподарської продукції, виручка від реалізації якої становить не менше 50\% загальної суми виручки.

Отже, зважаючи на наявні нормативно-правові акти 2012 року, потрібно відзначити, що в Україні було створено унікальну структуру, яка поєднує функції щодо управління землями державної власності та кредитного забезпечення сільськогосподарського виробництва, зокрема, під заставу земельних ділянок сільськогосподарського призначення.

Перспективи діяльності фінустанови було обговорено представниками Державного земельного банку з європейськими радниками із земельних питань, також було проаналізовано світову практику передачі державних сільськогосподарських земель у статутний капітал банку, механізми моніторингу землі, шляхи запобігання корупційних ризиків. Закордонні експерти ознайомили представників створеної фінансової установи з подібними перетвореннями у Франції, Німеччині, Литві, Болгарії та відзначали, що створення Державного земельного банку в Україні - це важлива подія на шляху економічних перетворень [13].

Однак створення Державного земельного банку викликало гостру критику з боку іноземного бізнесу, національних агрохолдингів і банківського сектору, окремих експертів. Представники іноземного бізнесу критикували нормативну базу створення Державного земельного банку за закріплення права отримання власності на сільськогосподарські землі лише за громадянами - 


\section{EФM \\ http://efm.vsau.org/}

фізичними особами (не більше 100 га в одні руки), державою в особі органів виконавчої влади, Державного земельного банку і територіальними громадами, тоді як іноземці та юридичні особи були позбавлені такого права. Агрохолдинги до цього переліку додавали жорсткі, на їхню думку, обмеження щодо оренди (6 тис. га - в одному районі, 5\% - в межах області). Банківський сектор не влаштовувало фактичне усунення його 3 ринку аграрного кредитування (зокрема, через норми про виключне право Державного земельного банку бути заставоутримувачем земель) [12, с. 112].

$\mathrm{He}$ підтримали ідею створення Державного земельного банку i міжнародні фінансові організації, членом яких $є$ Україна. Так, постійний представник МВФ в Україні публічно закликав український уряд утриматися від поспішних рішень про створення нових фінансових установ, зокрема й таких, як Державний земельний банк, звернувшись до міжнародного досвіду, який свідчить, що результати діяльності подібних установ малоефективні і потребують значних витрат.

У 2014 р. Кабінет Міністрів України, у зв'язку з неповним законодавчим забезпеченням роботи Державного земельного банку як суб'єкта правовідносин на ринку земель сільськогосподарського призначення, відсутністю прописаного механізму купівлі-продажу землі, що могло сприяти корупційним схемам, відсутністю концепції існування відповідного банку, яка б відповідала міжнародній практиці фінансування сільського господарства, ініціював рішення про ліквідацію Державного земельного банку (Постанова Кабінету Міністрів України від 10.09.2014 р. № 418) [14].

Проте, в Україні не всі погодилися з ліквідацією Державного земельного банку, зокрема науковці в аграрній сфері. Так, Лупенко Ю.О. зазначав, що «рішення Уряду України щодо ліквідації державного земельного банку зупиняє формування ринку сільськогосподарських земель у країні, й відмова Уряду від уже створеної, хоча і неповнофункціональної структури, загострює проблему кредитування аграрного виробництва, яку все одно доведеться вирішувати» [15].

На думку науковців $[4,7,12,15]$, Державний земельний банк може стати державним регулятором ринку сільськогосподарських земель, зокрема, шляхом підтримки відповідної ліквідності земельних ділянок та прав на них.

Якщо звернутися до досвіду інших країн, то варто відзначити, що для зарубіжних країн притаманною $є$ така практика: країни створюють установи 3 управління державними землями, а також сприяють прямо чи опосередковано створенню спеціалізованих фінансових установ, таких як гарантійні фонди, кредитні кооперативні установи, іпотечні банки та іпотечні установи другого рівня, які забезпечують розвиток кредитування сільського господарства. Завданнями цих установ $\epsilon$ забезпечення приватизації земель, здійснення управління державними землями, консолідація подрібнених земельних ділянок, забезпечення розвитку сільських територій та створення нових фермерських 
господарств.

Так, в Угорщині, згідно $з$ діючим законодавством, основними цілями Національного земельного фонду $\epsilon$ ефективне управління державними земельними ділянками, сприяння використанню сільськогосподарських угідь у контексті екологічного ведення сільськогосподарського виробництва, економічної ефективності, рентабельності, а також консолідації земельних ділянок [16].

Щодо варіантів інституційної форми земельного банку наглядним $є$ досвід Литви. Головною метою діяльності Земельного банку Литви $є$ стимулювання розвитку життєздатної структури землекористування у сільській місцевості.

Пріоритети діяльності Земельного банку Литви [17]:

- створити конкурентоспроможну фермерську структуру шляхом скорочення фрагментації та збільшення території невеликих i середніх агропромислових фермерських господарств (5-50 га);

- скоротити обсяг покинутих сільськогосподарських земель через відродження фермерства або зміну цільового призначення земельної ділянки залежно від родючості грунту і місця розташування ділянки;

- поліпшити структуру землекористування за допомогою консолідації земельних ресурсів для майбутніх i поточних потреб інфраструктури на місцевому, регіональному та національному рівнях.

У країнах СС створено декілька різновидів земельних банків із різними цілями i завданнями. Наприклад, у Нідерландах існує три основні форми діяльності земельних банків [17]:

- банк обміну земель (відновлювальний фонд для обміну земельними ділянками державної власності та земельними ділянками приватної власності на реалізацію певних цілей, наприклад, розвиток екологічних мереж);

- земельний банк, як засіб розвитку (земельна ділянка державної власності продається або здається в оренду, щоб забезпечити фермерів ширшими можливостями для різних заходів, наприклад, для збереження біологічного різноманіття);

- земельний банк, як фінансовий інструмент (земельна ділянка державної власності використовується 3 метою збільшення фермерських господарств через продаж або надання фермерам земельної ділянки в довгострокову оренду для збереження життєздатної сільськогосподарської діяльності на територіях, де управління земельними ресурсами обмежене заради збереження природи).

Натомість, у Португалії діяльність земельного банку наразі обмежена загальними рамками проєктів консолідації земельних ресурсів.

У Данії основною метою створення і функціонування державного земельного банку було покращення структури фермерських господарств. Згодом мета була розширена i передбачала зниження рівня державного втручання на сільських територіях. 


\section{EФM}

http://efm.vsau.org/

У Польщі основною ціллю діяльності Агентства сільськогосподарської власності було визначено приватизацію земель державної власності. Інші цілі, а саме: постійний моніторинг ринку сільськогосподарських земель, підтримка фермерських господарств тощо, були конкретизовані згодом.

Різноманітність форм земельних банків і структур, прирівняних до них, у зарубіжних країнах (Угорщина, Литва, Португалія, Польща) модифікуються від державних установ до товариств акціонерного типу. В більшості випадків, земельні банки виступають у формі державних установ національного рівня.

Отже, досвід країн Європейського Союзу, а також багатьох інших розвинених країн підтверджує необхідність функціонування державного банку земель або структур, прирівняних до нього. Ефективне державне управління сільськогосподарським землекористуванням у ринкових умовах може бути успішним за умов функціонування Державного земельного банку, який виконуватиме функції регулятора ринку та розпорядника державних сільськогосподарських земель.

Повертаючись до питання Державного земельного банку в Україні, варто зазначити, що для можливості його ефективної діяльності необхідно істотно коригувати законодавство України. На думку Кулинича П.Ф., для можливості функціонування Державного земельного банку, по-перше, необхідно внести певні зміни до Конституції України, яка передбачає, що розпорядження землями державної власності від імені держави-власника можуть здійснювати лише органи влади, а Державний земельний банк $є$ державною юридичною особою, що не наділена повноваженнями щодо розпорядження землями чинним земельним законодавством. По-друге, існують законодавчі обмеження щодо розпорядження банком землями державної власності, які будуть передані йому до статутного капіталу. Зокрема, згідно зі ст. 92 Земельного кодексу України, землі державної власності можуть надаватися державним юридичним особам, до яких належить і Державний земельний банк, тільки у постійне користування. Однак, постійний землекористувач наділений лише двома правами - володіння і користування землею, а тому не зможе здійснювати операції із земельними ділянками, такі як продаж, передача в оренду тощо [18, с. 14].

Міністерством аграрної політики та продовольства України декларувалося, що функціонування Державного земельного банку мало б забезпечити аграрних товаровиробників кредитами під 10\% річних. При цьому не було чітко регламентовано в нормативних документах, які механізми будуть використовуватися для формування дешевої ресурсної бази іпотечного банку. В цілому за інформацією із урядових структур та науково-дослідних інститутів, які брали участь у створенні Державного земельного банку, основними джерелами ресурсної бази передбачалися: кошти державного бюджету на формування статутного капіталу банку в сумі 120 млн грн, емісія банківських земельних облігацій - 27 млрд грн, передача в оперативний лізинг (оренду) земель - 1,8 млрд грн, залучення грошових коштів юридичних та фізичних осіб 


\section{EФM}

http://efm.vsau.org/

4 млрд грн, зовнішні запозичення - 15 млрд грн [16].

Також передбачалося, що розвиток кредитування під заставу земель сільськогосподарського призначення не буде нарощуватися швидкими темпами, навіть при знятті мораторію. Зазначене обумовлено існуючим протиріччям між дрібними та великими землекористувачами в Україні. Аналіз діяльності суб'єктів аграрного ринку спонукає до висновку, що більшість власників сільськогосподарських угідь передавали свої землі в оренду, а потребу в кредитах мали, в основному, товаровиробники, які виступають як орендарі земельних ділянок, а отже, не можуть використовувати останні як заставу. Пропонувалося масово використовувати як заставу право оренди, але це вимагає розробки ефективного методичного інструментарію щодо оцінки права оренди та механізму його провадження.

Нині, в Україні фактично не існує інструментів іпотечного кредитування під заставу сільськогосподарських земель, тому, для повної реалізації зазначеного доленосного проєкту зі створення Державного земельного банку, необхідно ще серйозно працювати на законодавчому рівні.

Також в Україні залишається недостатньо розвинутою сфера оцінки нерухомого майна і потребують доопрацювання законодавчі акти про оцінку майна, оцінку земель [19, с. 199]. У цих нормативно-правових актах необхідно переглянути вимоги, які ставляться щодо експертної грошової оцінки нерухомого майна, зокрема земельних ділянок. Доопрацювання також потребують і Національні стандарти оцінки нерухомого майна, рівень яких поки не відповідає рівневі Міжнародних стандартів оцінки. Також необхідно вдосконалити діючі та розробити нові методики грошової оцінки земельних ресурсів різного призначення.

У сучасних глобально-трансформаційних умовах ринку в Україні досі не створена єдина Державна кадастрово-реєстраційна система, хоча розроблено відповідну методологічну, нормативно-правову та методичну основу такої системи. Сьогодні існує велика кількість реєстрів, залежно від різних видів нерухомого майна та прав на нього. У результаті відсутнє бачення об'єкта нерухомого майна та прав на нього, як єдиного цілого, а збір різної інформації не дає цілісної уяви про об'єкт і вимагає значних витрат часу і фінансових ресурсів.

На основі аналізу зарубіжного досвіду функціонування державного земельного банку та структур, прирівняних до нього, i особливостей вітчизняних реалій, нами розроблено три можливі моделі створення i функціонування Державного земельного банку України (табл. 1).

На практиці контроль держави першочергово полягає у збереженні в державній власності необхідної кількості земель для впливу на ціну землі та право пріоритетного викупу усіх земель, які виставляються на продаж чи надаються в оренду [21, с. 19]. Створення державного земельного банку в Україні визначатиме його основну функцію - регулятора земельних відносин. 


\section{EФM}

http://efm.vsau.org/

Таблиия 1

\section{Моделі створення Державного земельного банку України}

\begin{tabular}{|c|c|}
\hline Модель 1 & $\begin{array}{l}\text { ержавний земельний банк повинен бути створений і функціонувати як за } \\
\text { грияння держави, так і за участі комерційних фінансово-кредитних установ. } \\
\text { изначальна роль у цьому разі належить банкам, які довгий час здійснюють } \\
\text { едитування сільського господарства, що забезпечить, із одного боку, } \\
\text { абільність фінансово-кредитного інституту, а } 3 \text { іншого - розширить } \\
\text { ожливості до рефінансування. }\end{array}$ \\
\hline & $\begin{array}{l}\text { Створення Державного земельного банку відбувається за сприяння держави, але } \\
\text { із залученням приватного капіталу. В подальшому передбачається поступове } \\
\text { зниження ролі держави у процесі функціонування земельно-іпотечної установи. } \\
\text { Проте, для створення такої спеціалізованої фінансової установи необхідне } \\
\text { залучення значних фінансових ресурсів із державного бюджету, що не } \\
\text { гарантуватиме ефективність такого кредитування. }\end{array}$ \\
\hline Модель 3 & $\begin{array}{l}\text { Дана модель створення i функціонування Державного земельного банку } \\
\text { розглядається як синергія двох вищезазначених моделей, що полягає у } \\
\text { безпосередній участі держави у спеціальному кредитуванні, але на базі } \\
\text { комерційних банків. У такому разі йдеться про здешевлення державою } \\
\text { відповідних кредитів, що передбачає певні фінансові видатки з державного } \\
\text { бюджету країни. Це може бути найменш ризикованим та найменш фінансово } \\
\text { затратним механізмом такого кредитування. }\end{array}$ \\
\hline
\end{tabular}

Джерело: розроблено авторами на основі даних [20]

Висновки. В умовах проведення земельної реформи, зважаючи на особливості створення Державного земельного банку в Україні, можна стверджувати, що установа функціонуватиме не лише як універсальна фінансова, що співпрацює з комерційними банками 3 питань рефінансування, надання гарантій, а й як спеціалізована, яка братиме на себе частину ризиків, що пов'язані із кредитуванням сільськогосподарських виробників, зокрема, i під купівлю земель сільськогосподарського призначення.

Для забезпечення повноцінного та ефективного запровадження i функціонування ринку земель сільськогосподарського призначення необхідно створити правове поле функціонування відповідної спеціалізованої інфраструктури і системи державного регулювання. Створюючи інституційні та ринкові передумови, забезпечується збалансованість на ринку земель, що дозволить виробникам сільськогосподарської продукції безперешкодно здійснювати купівлю-продаж землі, кредитувати малі та середні аграрні підприємства під відсотки, що забезпечить ефективність їх функціонування.

\section{Список використаних джерел}

1. Про внесення змін до деяких законодавчих актів України щодо умов обігу земель сільськогосподарського призначення: Закон України від 31 березня 2020 року № 552-IX. URL: https://zakon.rada.gov.ua/laws/show/552-20\#Tехt (дата звернення 05.06.2021).

2. Скоропадський П. Спогади (кінець 1917 - грудень 1918). / За ред. 
Я. Пеленського. Київ. Філадельфія, 1995. 494 с.

3. Гай-Нижник П.П. Український Державний Земельний банк в світлі офіційних документів Гетьманату 1918 р. Украӥнський селянин. 2008. Вип. 11. C. 27-29.

4. Саблук П.Т. Невідкладні заходи для врахування при запровадженні ринкових земельних відносин. Економіка АПК. 2020. № 2. С. 126-134. DOI: https://doi.org/10.32317/2221-1055.202002126.

5. Лупенко Ю.О., Ходаківська О.В. Моделі обігу земель сільськогосподарського призначення: результати анкетних досліджень. Економіка АПК. 2018. № 9. С. 5-15.

6. Степаненко Т.О. Теоретичні положення обігу земель сільськогосподарського призначення. Економіка АПК. 2017. № 3. С. 65-70.

7. Данкевич В.С. Розвиток земельних відносин у сільському господарстві: теорія, методологія, практика: дис. ... доктора екон. наук : 08.00.03. Житомир: ЖНАЕУ, 2017. 591 с.

8. Земельний кодекс України від 25.10.2001 p. № 2768, URL: http://zakon3.rada.gov.ua/laws/show/2768-14 (дата звернення: 31.05.2021 p.).

9. Кириленко І.Г. Капіталізація земельних ресурсів в умовах розвитку і трансформації земельних відносин в Україні. Економіка, фінанси, менеджмент: актуальні питання науки і практики. 2017. № 12 (28). С. 7-20.

10. Про створення Державного земельного банку: Постанова Кабінету Міністрів України від 02.07.2012 р. № 609 (Постанова втратила чинність на підставі постанови Кабінету Міністрів України № 418 від 10.09.2014р.). URL: https://zakon.rada.gov.ua/laws/show/609-2012-п (дата звернення: 01.06.2021 p.).

11. Про Державний земельний банк України: Проєкт Закону України від 10.04.2009 № 4337.

URL: http://search.ligazakon.ua/l_doc2.nsf/link1/JF3CH00A.html (дата звернення: 03.06.2021 p.).

12. Картамишева О.С. До питання про створення державного земельного (іпотечного) банку в Україні. Право і суспільство. 2020. № 2. Ч. 2. C. 109-115. DOI: https://doi.org/10.32842/2078-3736/2020.1-2.19.

13. Земельний банк вивчає світовий досвід. Аграрний тиждень. 31.12.2013. URL: https://news.realt.ua/novosti-nedvizhimosti-2/zemlya11/zemelnyy-bank-izuchaet-mirovoy-opyt-89666.html (дата звернення: 03.06.2021).

14. Про ліквідацію публічного акціонерного товариства «Державний земельний банк»: Постанова Кабінету Міністрів України від 10.09.2014 р. № 418. URL: https://zakon.rada.gov.ua/laws/show/418-2014-п (дата звернення: 04.06.2021).

15. Лупенко Ю.О. Ліквідація державного земельного банку 


\section{EФM}

http://efm.vsau.org/

відтерміновує формування ринку сільськогосподарських земель в Україні. URL: http://www.iae.org.ua/presscentre/agroproblem.html (дата звернення: 04.06.2021).

16. Олійник О. Державний земельний банк: мета створення та організація діяльності. URL: http://agro-business.com.ua/agro/ekspertnadumka/item/8158-derzhavnyi-zemelnyi-bank-meta-stvorennia-ta-orhanizatsiiadiialnosti.html (дата звернення: 05.06.2021).

17. Гринчук С.В. Зарубіжний досвід функціонування системи земельно-іпотечного кредитування та можливість його застосування в Україні. Ефективна економіка $2013 . \quad$ № 5. URL: http://www.economy.nayka.com.ua/?op=1\&z=2041 (дата звернення: 05.06.2021).

18. Кулинич П.Ф. Банк - на землі, а земля - в банку. Юридичний вісник України. 2012. № 39. С. 10-16.

19. Логоша Р.В. Формування постіндустріального ринку овочевої продукції в Україні: монографія. Вінниця: ПрАТ «Вінницька обласна друкарня», 2017. 515 с.

20. Костенко С.О. Земельний банк в Україні - бути чи не бути: аналіз 3 точки зору перспективного законодавства. Правова держава. 2019. № 34. С. $42-$ 47. DOI: https://doi.org/10.18524/2411-2054.2019.34.169532.

21. Kaletnik G., Honcharuk I., Yemchyk T., Okhota Yu. The World Experience in the Regulation of the Land Circulation. European Journal of Sustainable Development. 2020. № 9 (2). P. 557-568. DOI: 10.14207/ejsd.2020.v9n2p557.

22. Калетнік Г.М., Гончарук І.В., Смчик Т.В., Лутковська С.М. Аграрна політика та земельні відносини. Вінниця: ВНАУ, 2020. 307 с.

\section{References}

1. Pro vnesennya zmin do deyakyh zakonodavchyh aktiv Ukrayiny shhodo umov obigu zemel silskogospodarskogo pryznachennya: Zakon Ukrayiny [Law of Ukraine «On Amendments to Certain Legislative Acts of Ukraine Concerning the Conditions of Circulation of Agricultural Lands»] № 552-IX. (2020, March 31). zakon.rada.gov.ua. Retrieved from: https://zakon.rada.gov.ua/laws/show/552-20\#Text [in Ukrainian].

2. Skoropadskyi, P. (1995). Spohady (kinets 1917 - hruden 1918).[Memoirs (end of 1917 - December 1918)]. Ya. Pelenskiy (Ed.). Kyiv. Filadelfiia [in Ukrainian].

3. Hai-Nyzhnyk, P.P. (2008). Ukrainskyi Derzhavnyi Zemelnyi bank v svitli ofitsiinykh dokumentiv Hetmanatu 1918 r. [Ukrainian State Land Bank in the light of official documents of the Hetmanate of 1918]. Ukrainskyi selianyn Ukrainian peasant, 11, 27-29 [in Ukrainian].

4. Sabluk, P.T. (2020). Nevidkladni zakhody dlia vrakhuvannia pry zaprovadzhenni rynkovykh zemelnykh vidnosyn [Immediate measures to take into account when introducing market land relations]. Ekonomika APK - Economics of 
agro-industrial complex, 2, 126-134. DOI: https://doi.org/10.32317/22211055.202002126 [in Ukrainian].

5. Lupenko, Yu.O., \& Khodakivska, O.V. (2018). Modeli obihu zemel silskohospodarskoho pryznachennia: rezultaty anketnykh doslidzhen [Models of agricultural land turnover: results of questionnaires]. Ekonomika APK - Economics of agro-industrial complex, 9, 5-15 [in Ukrainian].

6. Stepanenko, T.O. (2017). Teoretychni polozhennia obihu zemel silskohospodarskoho pryznachennia [Theoretical provisions for the circulation of agricultural land]. Ekonomika APK - Economics of agro-industrial complex, 3, 65-70 [in Ukrainian].

7. Dankevych, V.Ie. (2017). Rozvytok zemelnykh vidnosyn u silskomu hospodarstvi: teoriia, metodolohiia, praktyka [Development of land relations in agriculture: theory, methodology, practice]. Doctor's thesis. Zhytomyr: ZhNAEU [in Ukrainian].

8. Zemelnyi kodeks Ukrainy [Land Code of Ukraine]. (2001, October 25). zakon.rada.gov.ua. Retrieved from: http://zakon.rada.gov.ua/laws/show/2768-14 [in Ukrainian].

9. Kyrylenko, I.G. (2017). Kapitalizaciya zemelnyh resursiv v umovah rozvytku i transformaciyi zemelnyh vidnosyn $\mathrm{v}$ Ukrayini [Capitalization of land resources in terms of development and transformation of land relations in Ukraine]. Ekonomika, finansi, menedzhment: aktualni pitannya nauki i praktiki - Economics, finance, management: topical issues of science and practical activity, 12 (28), 7-20 [in Ukrainian].

10. Postanova Kabinetu Ministriv Ukrainy «Pro stvorennia Derzhavnoho zemelnoho banku» [Resolution of the Cabinet of Ministers of Ukraine «About creation of the State land bank»] (2012, July 2). zakon.rada.gov.ua. Retrieved from: https://zakon.rada.gov.ua/laws/show/609-2012-p [in Ukrainian].

11. Proekt Zakonu Ukrainy «Pro Derzhavnyi zemelnyi bank Ukrainy» [Draft Law of Ukraine «About the State Land Bank of Ukraine»]. (2009, April 10). search.ligazakon.ua. Retrieved from: http://search.ligazakon.ua/__doc2.nsf/link1/JF3CH00A.html [in Ukrainian].

12. Kartamysheva, O.Ie. (2020). Do pytannia pro stvorennia derzhavnoho zemelnoho (ipotechnoho) banku v Ukraini [On the issue of establishing a state land (mortgage) bank in Ukraine]. Pravo i suspilstvo - Law and society, 2, 2, 109-115. DOI: https://doi.org/10.32842/2078-3736/2020.1-2.19 [in Ukrainian].

13. Zemelnyi bank vyvchaie svitovyi dosvid [The Land Bank studies world experience]. (2013). news.realt.ua. Retrieved from: https://news.realt.ua/novostinedvizhimosti-2/zemlya-11/zemelnyy-bank-izuchaet-mirovoy-opyt-89666.html [in Ukrainian].

14. Postanova Kabinetu Ministriv Ukrainy «Pro likvidatsiiu publichnoho 


\section{EФM}

http://efm.vsau.org/

aktsionernohotovarystva «Derzhavnyi zemelnyi bank»»»[ [Resolution of the Cabinet of Ministers of Ukraine «On liquidation of the public joint-stock company «State Land Bank»»)] (2014, September 10). zakon.rada.gov.ua. Retrieved from: https://zakon.rada.gov.ua/laws/show/418-2014-p. [in Ukrainian].

15. Lupenko, Yu.O. Likvidatsiia derzhavnoho zemelnoho banku vidterminovuie formuvannia rynku silskohospodarskykh zemel $\mathrm{v}$ Ukraini [The liquidation of the state land bank delays the formation of the agricultural land market in Ukraine]. iae.org.ua. Retrieved from: http://www.iae.org.ua/presscentre/ agroproblem.html [in Ukrainian].

16. Oliinyk, O. Derzhavnyi zemelnyi bank: meta stvorennia ta orhanizatsiia diialnosti [State Land Bank: the purpose of creation and organization of activities]. agro-business.com.ua. Retrieved from: http://agro-business.com.ua/agro/ekspertnadumka/item/8158-derzhavnyi-zemelnyi-bank-meta-stvorennia-ta-orhanizatsiiadiialnosti.html [in Ukrainian].

17. Hrynchuk, S.V. (2013). Zarubizhnyi dosvid funktsionuvannia systemy zemelno-ipotechnoho kredytuvannia ta mozhlyvist yoho zastosuvannia $\mathrm{v}$ Ukraini [Foreign experience of land mortgage lending system and the possibility of its application in Ukraine]. Efektyvna ekonomika - Efficient economy, 5. Retrieved from: http://www.economy.nayka.com.ua/?op=1\&z=2041[in Ukrainian].

18. Kulynych, P.F. (2012). Bank - na zemli, a zemlia - v banku [The bank is on the ground, and the land is in the bank]. Yurydychnyi visnyk Ukrainy - Legal Bulletin of Ukraine, 39, 10-16 [in Ukrainian].

19. Logosha, R.V. (2017). Formuvannia postindustrialnoho rynku ovochevoi produktsii v Ukraini [Formation of post-industrial market for vegetable products in Ukraine]. Vinnytsia: PrAT «Vinnytska oblasna drukarnia» [in Ukrainian].

20. Kostenko, S.O. (2019). Zemelnyi bank v Ukraini - buty chy ne buty: analiz z tochky zoru perspektyvnoho zakonodavstva [Land Bank in Ukraine - to be or not to be: an analysis in terms of future legislation]. Pravova derzhava Constitutional state, 34, 42-47. DOI: https://doi.org/10.18524/24112054.2019.34.169532 [in Ukrainian].

21. Kaletnik, G., Honcharuk, I., Yemchyk, T., \& Okhota, Yu. (2020). The World Experience in the Regulation of the Land Circulation. European Journal of Sustainable Development, 9 (2), 557-568. DOI: 10.14207/ ejsd.2020.v9n2p557 [in English].

22. Kaletnik, G.M., Goncharuk, I.V., Yemchyk, T.V., \& Lutkovska, S.M. (2020). Agrarna polityka ta zemelni vidnosyny [Agrarian policy and land relations]. Vinnytsia: VNAU [in Ukrainian].

\section{Відомості про авторів}

ЛОГОША Роман Васильович - доктор економічних наук, доцент кафедри аграрного менеджменту та маркетингу, Вінницький національний аграрний університет (21008, м. Вінниця, вул. Сонячна, 3, e-mail: 


\section{EФM}

http://efm.vsau.org/

1rv@vsau.vin.ua).

ХАЄЦЬКА Ольга Петрівна - кандидат економічних наук, доцент, завідувачка кафедри економіки та підприємницької діяльності, Вінницький національний аграрний університет (21008, м. Вінниця, вул. Сонячна, 3, e-mail: haetska@vsau.vin.ua).

LOGOSHA Roman - Doctor of Economic Sciences, Associate Professor of the Department of Agricultural Management and Marketing, Vinnytsia National Agrarian University (21008, Vinnytsia, 3, Soniachna Str., e-mail: lrv@ vsau.vin.ua).

KHAIETSKA Olha - Candidate of Economic Sciences, Associate Professor, Head of the Department of Economics and Entrepreneurship, Vinnytsia National Agrarian University (21008, Vinnytsia, 3, Soniachna Str., e-mail: haetska@ivsau.vin.ua).

ЛОГОША Роман Васильевич - доктор экономических наук, доцент кафедры аграрного менеджмента и маркетинга, Винницкий национальный аграрный университет $(21008$, г. Винница, ул. Солнечная, 3, e-mail: 1rv@vsau.vin.ua).

ХАЕЦКАЯ Ольга Петровна - кандидат экономических наук, доцент, заведующая кафедрой экономики и предпринимательской деятельности, Винницкий национальный аграрный университет (21008, г. Винница, ул. Солнечная, 3, e-mail: haetska@vsau.vin.ua).

УДК 620.925:332.2

DOI: $10.37128 / 2411-4413-2021-3-4$

ПЕРСПЕКТИВИ

ВИРОБНИЦТВА

БІОПАЛИВ В

УМOBAX

РЕФОРМУВАННЯ

ЗЕМЕЛЬНИХ

ВІДНОСИН
ФУРМАН I.В., кандидат економічних наук, доцент кафедри адміністративного менеджменту та альтернативних джерел енергї, Вінницький національний аграрний університет

РАТУШНЯК Н.О., викладач,

Відокремлений структурний підрозділ "Технологічно-промисловий фаховий коледэс Вінницького національного аграрного університету" (м. Вінниця)

У статті досліджено нормативну грошову оцінку земель сільськогосподарського призначення в областях Украӥни. Проаналізовано динаміку зміни посівних площ основних сільськогосподарських культур. Визначено напрямки розвитку сільськогосподарського виробництва на короткострокову перспективу. Досліджено основні складові енергетичного 